\title{
WestVirginiaUniversity
}

THE RESEARCH REPOSITORY @ WVU

West Virginia Agricultural and Forestry Experiment

Davis College of Agriculture, Natural Resources

Station Bulletins

And Design

$1-1-1988$

\section{Biocontrol of the alfalfa weevil : a status report}

Joseph E. Weaver

Judith B. Shaffer

Follow this and additional works at: https://researchrepository.wvu.edu/ wv_agricultural_and_forestry_experiment_station_bulletins

\section{Digital Commons Citation}

Weaver, Joseph E. and Shaffer, Judith B., "Biocontrol of the alfalfa weevil : a status report" (1988). West Virginia Agricultural and Forestry Experiment Station Bulletins. 700.

https://researchrepository.wvu.edu/wv_agricultural_and_forestry_experiment_station_bulletins/594 @ WVU. It has been accepted for inclusion in West Virginia Agricultural and Forestry Experiment Station Bulletins by an authorized administrator of The Research Repository @ WVU. For more information, please contact ian.harmon@mail.wvu.edu. 


\section{Biocontrol of the}

\section{Alfalfa Weevil-A Status Report}

\section{Bulletin 700}

November, 1988

5127

E/ Agricultural and Forestry Experiment Station West Virginia University

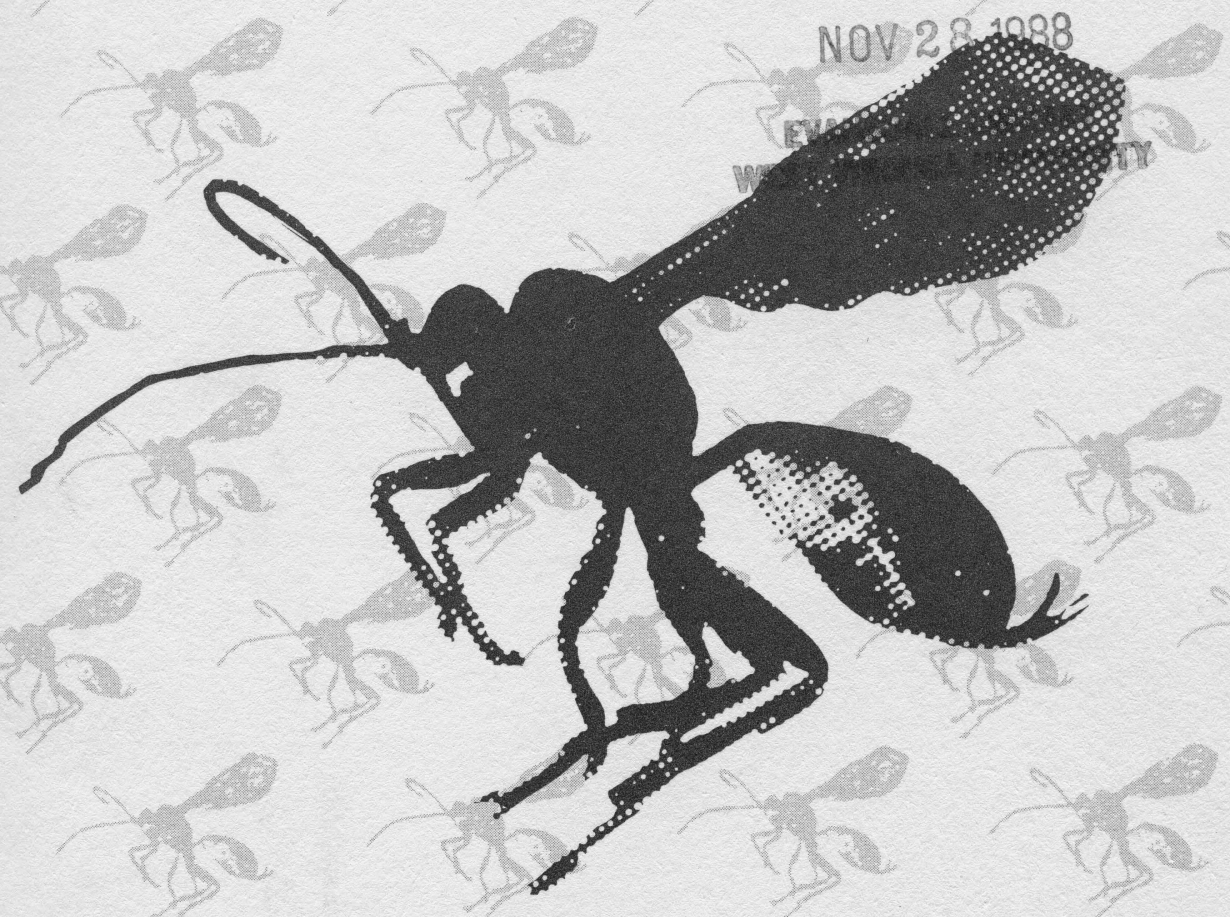




\title{
Authors
}

Joseph E. Weaver is associate professor, and Judith B. Shaffer is former graduate student, Division of Plant and Soil Sciences, College of Agriculture and Forestry, West Virginia University.

\author{
West Virginia University \\ Agricultural and Forestry Experiment Station \\ College of Agriculture and Forestry \\ Robert H. Maxwell, Director \\ Morgantown
}




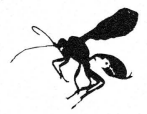

Introduction $\ldots \ldots \ldots \ldots \ldots \ldots \ldots \ldots \ldots \ldots \ldots \ldots \ldots$

Materials and Methods ...................... 3

Results and Discussion ..................... 5

Insect Parasitism and Fungal Infection Levels........ 5

Comparison of Parasitism and Fungal Infection Levels

in Reared and Dissected Larvae............... 7

Visual Diagnosis of Fungal Infection ........... 8

Distribution of Parasites 1972-73 and 1985-1986 ..... 8

Hyperparasites found in West Virginia ........... 9

Alfalfa Weevil Populations ................... 11

Conclusions ............................ 11

Literature Cited ....................... 13 


\section{Blank Page in Original Bulletin}




\title{
Biocontrol of the Alfalfa Weevil in West Virginia-A Status Report
}

\author{
Joseph E. Weaver and Judith B. Shaffer
}

\section{Introduction}

The most important insect pest of first harvest alfalfa is the alfalfa weevil, Hypera postica (Gyllenhall) [3]. Serious losses caused by the weevil were first reported in the Eastern Panhandle of West Virginia in 1955, one season after it was first observed in the state [12]. By 1961 every alfalfa-growing area of West Virginia was affected by the weevil.

Alfalfa acreage decreased dramatically in West Virginia between 1958 and 1967 (Fig. 1). Stuart [10] cited an unpublished survey conducted by C. F. Bishop (WVU Cooperative Extension Service) in 1966 indicating the majority of West Virginia county agents attributed the drastic drop in alfalfa acreage to weevil damage. Although there may have been other factors contributing to the decrease in alfalfa acreage, the alfalfa weevil was a major factor.

Several insect parasites have been imported and released as biocontrol agents in West Virginia since 1961. Dates and locations of releases made from 1961 through 1975 were reported by Weaver [12]. Species of parasitic wasps released were Bathyplectes curculionis (Thomson), Bathyplectes anurus (Thomson), Microctonus aethiopoides (Loan), Tetrastichus incertus (Ratzeburg), and Diabrachoides druso (Walker). According to Weaver and Gallo [13], all of these species except $D$. druso were recovered subsequent to release. Two other species, Microctonus colesi Drea and Patasson luna (Girault), that had not been released in the state also were found to attack the weevil.

During a 1972-73 survey by Gallo [2], B. curculionis and M. colesi were found to be the most widespread and abundant parasites; $T$. incertus also was widespread but was not as prevalent. Bathyplectes anurus was found at very low levels in only three counties.

In 1973, a fungal pathogen (Erynia sp.) of the weevil was discovered in Canada. In 1980, a limited survey in six West Virginia counties confirmed that Erynia sp. was also present here [11].

Despite evidence of the widespread establishment of at least two parasite species in West Virginia by the early 1970's, several reports [2, 14, and Weaver 1973, an unpublished report] indicated that chemical control was still necessary in some areas. Gallo's 1973 survey found that fields with the highest percent parasitism by $B$. curculionis had not required chemical control for three years. Weaver [1973, unpublished report], however, doubted the weevil 


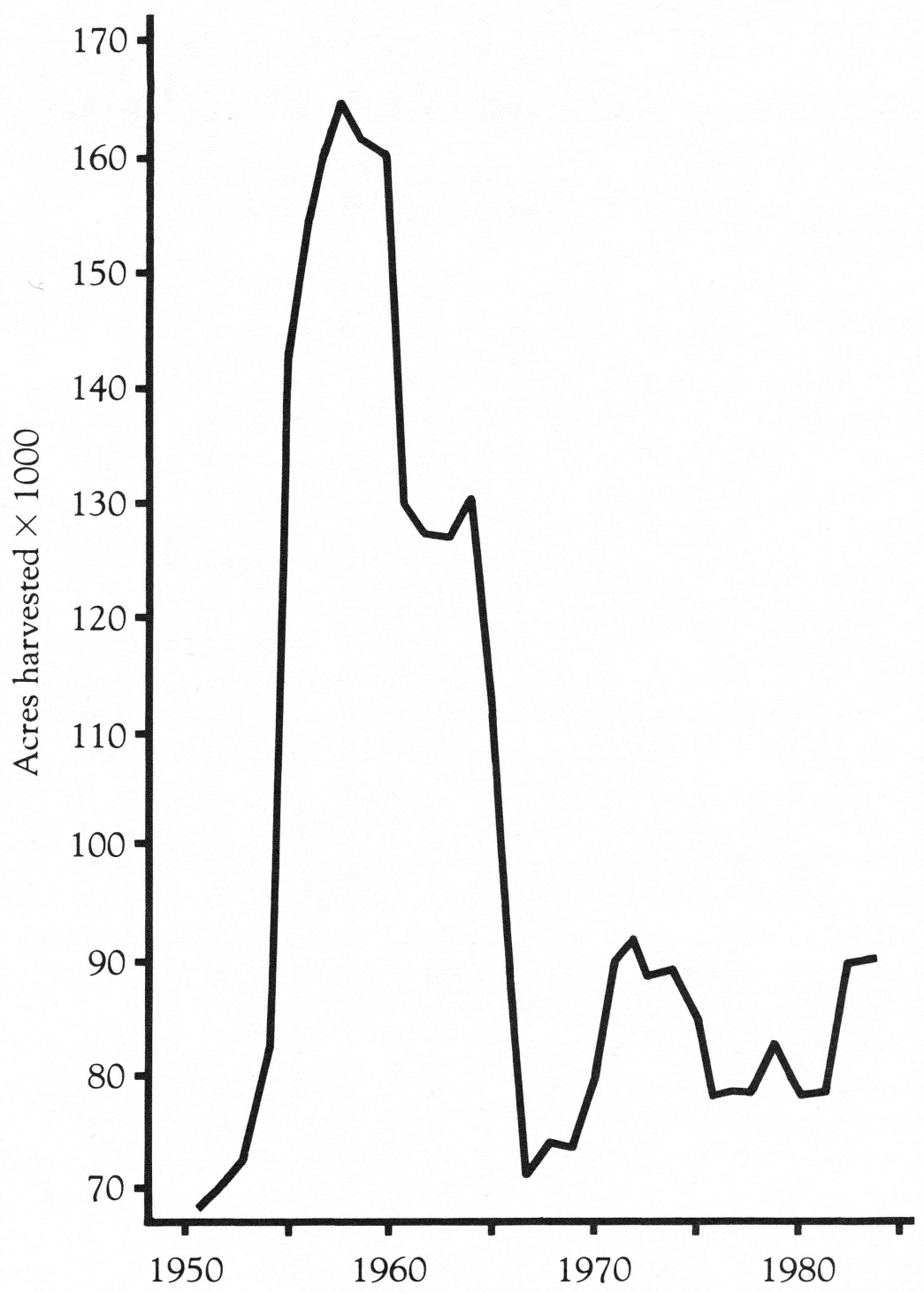

Figure 1. West Virginia Alfalfa Production (From WVDA Agricultural Statistics Annual Report)

could be held to sub-economic levels by the parasites then established. He also reported that there was a general statewide decline in weevil populations that had allowed farmers to control the weevil with fewer insecticide applications. Through conversations with farmers during the 1985 and 1986 seasons, it was learned that chemicals had been used recently for weevil control on some 
farms in Jefferson, Berkeley and Ohio counties, but not in Greenbrier, Preston, Monongalia, or Mason counties.

Since a comprehensive survey concerning the status of biological control of the alfalfa weevil in West Virginia had not been conducted for over ten years, this study was undertaken to assess the present status of the weevil and its associated biocontrol agents. The major objectives of the study were to determine: (1) which species of insect parasites were attacking the weevil in West Virginia in 1985 and 1986; (2) the population densities of present parasites; and (3) the infection rate of Erynia sp. in the major alfalfa production areas of the state. Additionally, data were gathered on weevil larval populations and hyperparasites associated with Bathyplectes spp. Hopefully, by learning the current status of the biological agents affecting alfalfa weevil in West Virginia we will be able to intelligently use integrated control methods for managing this pest.

\section{Materials and Methods}

Alfalfa weevil samples were taken from each geographical region of the state (Fig. 2). In 1985, the counties visited were Ohio, Monongalia, Preston, Berkeley, Jefferson, Hardy, and Greenbrier. In 1986, sampling was limited to only one county per geographical region. Mason County was added so the Southwestern region was included, and Jefferson and Hardy counties were dropped since they were in the Northeastern region with Berkeley County. The number of alfalfa fields sampled per county were: four in Ohio; one in Monongalia (another was added in 1986); three in Preston; four in Berkeley (another was added in 1986); two in Jefferson; two in Hardy; and four in Greenbrier. In 1986, four fields also were sampled in Mason County.

Fields were sampled before, during, and after larval population peaks, with early sampling beginning about the first week of April. One hundred 180degree sweeps were made per field using a $151 / 2$-inch diameter sweep net. These samples were frozen and used later for determining population levels. Some of the larvae in the 1985 samples were dissected to determine fungal infection rates and percent insect parasitism. Sweep samples also were taken from various areas of a given field so larvae could be reared to determine levels of parasitism and fungal infection. Overwintered adult weevils collected in early season sweep samples were maintained in the laboratory on alfalfa bouquets and checked periodically for Microctonus sp. emergence. Wasp emergence was recorded and the wasps were identified as $M$. colesi or M. aethiopoides. Eventually the adult weevils either died of natural causes or were killed by emergence of the parasites. In 1986, samples of field debris also were collected early in the season and processed by Berlese funnel in an attempt to isolate overwintering adults. These efforts were ineffective and the practice was discontinued. 


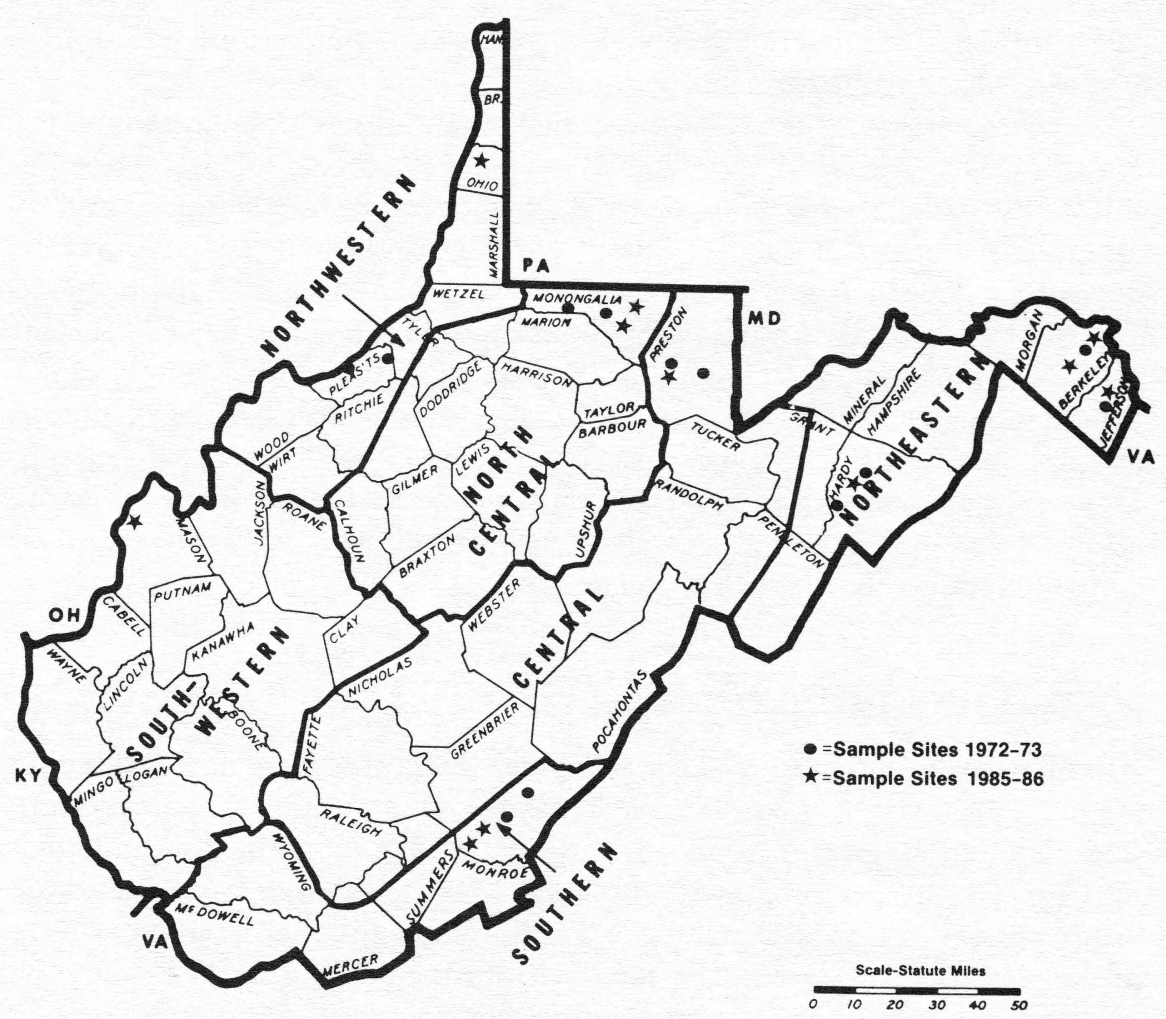

Figure 2. Alfalfa weevil parasite survey regions and sampling site locations.

During the latter part of the 1986 season, Bathyplectes spp. cocoons were collected from the study fields to be isolated for hyperparasite emergence. Cocoons were isolated separately in clear gelatin capsules which were then checked periodically and date of emergence and species of hyperparasite were recorded.

To assess parasitism of weevil larvae, 50 late instar larvae from each study field were held in plastic petri dishes with alfalfa bouquets and water and allowed to mature. Surviving adult weevils reared in this manner were provided with food and water as with larvae and held until the last week in July. These adults were then put in alcohol and later dissected to determine percent $M$. colesi parasitism.

Dates were recorded when Bathyplectes spp. cocoons or $H$. postica mummies containing $T$. incertus were formed from laboratory reared larvae. Weevil larvae which appeared to have died of fungal disease, including those which managed to spin cocoons, were placed in vials. These specimens were evaluated for the presence of the fungus following the 3 percent potassium 
hydroxide immersion method of Los and Allen [5], in which infected larvae produce a specific yellow or brown precipitate.

In 1985, weevil larvae from the samples collected for population counts were dissected to determine fungal infection. This proved to be a very time consuming process and visual identification of the fungus was highly subjective. This procedure was abandoned in the 1986 samples.

\section{Results and Discussion}

During the 1985 season, it was not possible to sample each site as planned before, during, and after peak larval populations. Preston County was sampled four times, Ohio County twice, and other counties only once. In 1986, Monongalia and Ohio counties were sampled three times, while Berkeley, Greenbrier, Mason, and Preston were sampled twice. Bathyplectes anurus was by far the most common parasite and was present in every county sampled. Other parasites found were B. curculionis, M. aethiopoides, $M$. colesi, and T. incertus.

\section{Insect Parasitism and Fungal Infection Levels (Table 1)}

Ohio County-Bathyplectes anurus and M. aethiopoides accounted for all the insect parasitism on the first visit to Ohio County in 1985. Erynia sp. was found in only 6 percent of the larvae from one field. One larva collected from this field in late April exhibited a noncharacteristic red precipitate when tested with the Los and Allen method. The color of the precipitate matched Color 1 OR 4/ 8 in the Munsell scale. On the second visit in 1985, B. anurus levels had decreased to 8 percent, but parasitism by $B$. curculionis had increased to 22 percent. Microctonus colesi and Erynia sp. were present on the second visit, but at low levels (1 percent each).

Except for B. curculionis, percent parasitism in Ohio County was higher in 1985 than in 1986. In addition, one T. incertus was found in 1986 but is not noted in Table 1. Erynia sp. infection occurred in all fields on all sampling dates, reaching a high of 90 percent in one field on the last sampling date. The high level of fungal infection seemed unusual because Ohio County was particularly dry during the 1986 season and fungal epizootics usually are always associated with high rainfall [4]. There had been instances of light rain which provided proper microclimatic conditions within the alfalfa canopy to encourage development of the fungus $[7,8,9]$.

Monongalia County - While the 1985 data from Monongalia County are limited (one field, one date), all weevil parasites sampled for were present. Erynia sp. was not detected.

In 1986, the fungus was present in both fields sampled. On the last sampling date, fungal infection accounted for 90 to 100 percent of the mortality in reared larvae. As the percentage of fungal infection increased, there was a 
Table 1

Percent parasitism and percent infection of alfalfa weevil larvae by four insect parasites and Erynia sp., 1985-1986.

\begin{tabular}{|c|c|c|c|c|c|c|c|}
\hline \multirow[b]{2}{*}{ County } & \multirow[b]{2}{*}{ Date } & \multirow{2}{*}{$\begin{array}{l}\text { No. of } \\
\text { fields } \\
\text { sampled }\end{array}$} & \multicolumn{4}{|c|}{ Mean \% parasitism } & \multirow{2}{*}{$\begin{array}{c}\text { Mean \% } \\
\text { infection by } \\
\text { Erynia sp. }\end{array}$} \\
\hline & & & B. a. ${ }^{1}$ & B. C. & M. c. & M. a. & \\
\hline \multicolumn{8}{|l|}{1985} \\
\hline Ohio & $4 / 25$ & 4 & $37(22-55)^{2}$ & 0 & 0 & $16(0-40)$ & $2(0-6)$ \\
\hline Ohio & $5 / 29$ & 2 & $8(6-10)$ & $22(18-26)$ & $1(0-2)$ & 0 & $1(0-2)$ \\
\hline Monongalia & $5 / 16$ & 1 & 20 & 2 & 6 & 3 & 0 \\
\hline Preston & $5 / 8$ & 2 & $24(18-30)$ & 0 & 0 & & 0 \\
\hline Preston & $5 / 15$ & 2 & $12(8-16)$ & 0 & 0 & & $6(4-8)$ \\
\hline Preston & $5 / 24$ & 2 & $4(4-4)$ & 0 & $1(0-2)$ & & $52(52-52)$ \\
\hline Preston & $5 / 30$ & 2 & $4(0-8)$ & 0 & 0 & & $66(60-72)$ \\
\hline Greenbrier & $4 / 30$ & 4 & $28(20-48)$ & $<1(0-2)$ & $1(0-2)$ & & $3(0-4)$ \\
\hline Berkeley & $5 / 13$ & 2 & $34(16-52)$ & $5(2-8)$ & 0 & & 0 \\
\hline Jefferson & $5 / 13$ & 2 & $27(22-32)$ & $7(4-10)$ & $2(2-2)$ & & $12(10-14)$ \\
\hline Hardy & $5 / 13$ & 2 & $8(6-10)$ & $4(0-8)$ & $2(0-4)$ & & $24(4-44)$ \\
\hline \multicolumn{8}{|l|}{1986} \\
\hline Ohio & $4 / 30$ & 4 & $54(40-66)$ & $1(0-2)$ & 0 & $43(36-52)$ & $17(12-20)$ \\
\hline Ohio & $5 / 15$ & 4 & $34(20-52)$ & $<1(0-2)$ & $2(0-4)$ & & $14(4-22)$ \\
\hline Ohio & $5 / 30$ & 4 & $5(2-10)$ & $10(2-12)$ & $1(0-2)$ & & $63(34-90)$ \\
\hline Monongalia & $4 / 28$ & 1 & 28 & 0 & 0 & 59 & 2 \\
\hline Monongalia & $5 / 6$ & 2 & $40(32-48)$ & $1(0-2)$ & $1(0-2)$ & 71 & $14(6-22)$ \\
\hline Monongalia & $5 / 29$ & 2 & $1(0-2)$ & 0 & 0 & & $95(90-100)$ \\
\hline Preston & $5 / 6$ & 3 & $45(34-58)$ & $<1(0-2)$ & 0 & $66(62-73)$ & $9(8-12)$ \\
\hline Preston & $5 / 29$ & 3 & $7(0-20)$ & $<1(0-2)$ & 0 & & $57(22-88)$ \\
\hline Greenbrier & $4 / 23$ & 3 & $54(36-86)$ & $5(0-8)$ & 0 & 0 & $<1(0-2)$ \\
\hline Greenbrier & $5 / 8$ & 4 & $43(30-52)$ & $1(0-2)$ & $3(0-6)$ & & $13(6-22)$ \\
\hline Berkeley & $5 / 1$ & 5 & $63(38-76)$ & $<1(0-2)$ & 0 & $25(0-44)$ & $11(4-16)$ \\
\hline Berkeley & $5 / 22$ & 4 & $4(2-8)$ & $3(0-12)$ & 0 & & $19(0-44)$ \\
\hline Mason & $4 / 25$ & 4 & $57(42-66)$ & $<1(0-2)$ & 0 & $30(0-67)$ & $7(2-14)$ \\
\hline Mason & $5 / 9$ & 4 & $13(2-26)$ & $<1(0-2)$ & $<1(0-2)$ & & $48(6-82)$ \\
\hline
\end{tabular}

1B. a. = Bathyplectes anurus

B. $c .=$ Bathyplectes curculionis

M. c. $=$ Microctonus colesi

M. a. = Microctonus aethiopoides

2Range

corresponding decrease in insect parasitism. This may be explained because as the fungus grows inside the weevil larva, any insect parasite present also will be killed.

Preston County - In 1985, Preston County samples yielded B. anurus in significant numbers whereas $M$. colesi was at a very low level. As the season progressed, the percent infection by Erynia sp. increased.

In 1986, B. anurus, B.curculionis and $M$. aethiopoides were found, but $M$. colesi was not. In one field, the levels of the most significant insect parasite, $B$. anurus, declined as Erynia sp. infection reached 88 percent.

Greenbrier County - In 1985, all species of insect parasites were found in Greenbrier County. Erynia sp. was present, but at low levels.

In 1986, all insect parasites were present except $M$. aethiopoides, with $B$. anurus being the only one found in large numbers. $M$. aethiopoides may not 
have been found due to a small sample size ( 9 adults). Although Erynia sp. was detected more often than in the previous year, the percent infection was much lower than in other areas of the state. It is interesting to note that in the absence of high levels of Erynia sp., B. anurus levels remained high throughout the season.

Berkeley County-Bathyplectes anurus and B. curculionis were present in Berkeley County in 1985, however, the data for that year are limited. Erynia $\mathrm{sp}$. was not detected in either of the fields sampled. However, over 90 percent of larvae in one of the fields sampled suffered fungal infection at the end of the 1985 season, and we presume the fungus was Erynia (personal communication, West Virginia University Agricultural Extension Service).

In 1986, M. colesi was the only insect parasite not found in Berkeley County. Erynia sp. was present in all fields, but not at the high levels of other regions. The relatively low level of Erynia sp. on May 1 (avg. 11 percent) seemed to be associated with high levels of $B$. anurus parasitism; e.g. 76, 74 and 70 percent in three of the fields sampled.

Jefferson and Hardy counties - The data from Jefferson and Hardy counties are so limited no extensive comment is warranted. However, two weevil larvae were parasitized by $T$. incertus; these were the only T. incertus found in 1985 . A sample obtained from Jefferson County in 1986 yielded three larvae that appeared to have been killed by Erynia sp. When tested by the method developed by Los and Allen, two of the larvae exhibited characteristic precipitates. The third formed a red precipitate which corresponded to color 1 OR 4/8 in the Munsell scale.

Mason County-All insect parasites and Erynia sp. were found in Mason County. Bathyplectes anurus parasitism was as high as 66 percent in one field on the first sampling date, and the mean percent parasitism by this species was the second highest observed in all counties for both years. Erynia sp. reached a high of 82 percent infection on the second sampling date but the mean percentage infection for that date was kept low because one field only had a 6 percent infection level.

\section{Comparison of Parasitism and Fungal Infection Levels in Reared and Dissected Larvae (Table 2)}

Rearing field collected larvae through the last stages of development was a more reliable method of determining parasitism and fungal infection levels than by dissection. Additionally, dissections of larvae were extremely time consuming, and fungal infection determinations were highly subjective.

Parasitism and fungal infection levels were about three times greater in reared larvae than in dissected larvae. Mean percent parasitism (all species) and mean percent infected larvae for all locations and collection dates of reared versus dissected larvae, respectively, were: 18.4 vs. 6.1 percent and 20.0 vs. 6.6 percent. 
Table 2

Percentage parasitism by Bathyplectes spp. and infection by Erynia sp. of reared and dissected alfalfa weevil larvae-1985.

\begin{tabular}{|c|c|c|c|c|c|c|}
\hline \multirow{3}{*}{ County } & \multirow{3}{*}{ Date } & \multicolumn{3}{|c|}{ Reared larvae } & \multicolumn{2}{|c|}{ Dissected larvae } \\
\hline & & \multicolumn{2}{|c|}{$\%$ parasitism $^{1}$} & \multirow{2}{*}{$\begin{array}{c}\% \\
\text { infected }\end{array}$} & \multirow{2}{*}{$\begin{array}{c}\% \\
\text { parasitism }\end{array}$} & \multirow{2}{*}{$\begin{array}{c}\% \\
\text { infected }\end{array}$} \\
\hline & & & & & & \\
\hline Ohio & $4 / 25$ & 37 & 0 & 2 & 10 & $<1$ \\
\hline Ohio & $5 / 29$ & 6 & 26 & 2 & 17 & 0 \\
\hline Preston & $5 / 8$ & 18 & 0 & 0 & 2 & 4 \\
\hline Preston & $5 / 15$ & 8 & 0 & 8 & 4 & 18 \\
\hline Preston & $5 / 24$ & 4 & 0 & 52 & 7 & 1 \\
\hline Preston & $5 / 30$ & 8 & 0 & 72 & 3 & 19 \\
\hline Greenbrier & $4 / 30$ & 22 & 0 & 4 & 0 & 4 \\
\hline
\end{tabular}

1B. a. = Bathyplectes anurus

B. $c .=$ Bathyplectes curculionis

2Species not determined.

\section{Visual Diagnosis of Fungal Infection (Table 3)}

Results of the visual diagnosis of Erynia infection of alfalfa weevil larvae cadavers by the Los and Allen method are given in Table 3. The yellow precipitate is diagnostic for the hyphal and conidial stage of Erynia sp. The brown precipitate is diagnostic for the resting spore stage. Resting spores were found in prepupae as well as larvae.

The red precipitate found during the diagnostic procedure for Erynia sp. corresponds to 1 OR 4/8 in the Munsell scale. It is not known what this red precipitate represents. Los and Allen [5] reported finding precipitates that did not match the characteristic yellow and brown, but they did not mention any specific colors they may have found. Of the few specimens they found that had questionable, uncharacteristic, or no precipitate, most were eventually found to be positive for Erynia sp. Some specimens were negative for any fungi, and still others contained unidentified fungi. All cadavers which contained the unidentified fungi did not form precipitates.

\section{Distribution of Parasites 1972-1973 and 1985-1986 (Table 4)}

A comparison of the distribution of established alfalfa weevil parasites in 1972-73 and 1985-86 is presented in Table 4. This shows an increase in the occurrence of both $M$. aethiopoides and B. anurus and a decline of $T$. incertus. The apparent absence of $M$. aethiopoides in the southern region may be due to the small sample size rather than its inability to establish there. The presence 


\section{Table 3}

Percent infection of alfalfa weevil larvae by Erynia sp. as determined by Los and Allen method, 1985-1986.

\begin{tabular}{|c|c|c|}
\hline Precipitate in Munsell Scale & $\begin{array}{c}\text { No. } \\
\text { examined }\end{array}$ & $\begin{array}{c}\% \\
\text { infected }\end{array}$ \\
\hline \multicolumn{3}{|l|}{1985} \\
\hline \multicolumn{3}{|l|}{ Brown $2.5 Y 4 / 4$} \\
\hline larvae & 93 & 42 \\
\hline prepupae & 48 & 22 \\
\hline Yellow 5Y 8/6-8/10 & 57 & 26 \\
\hline Red 1 OR 4/8 & 1 & $<1$ \\
\hline Negative & 23 & 10 \\
\hline Total \% infected & & 90 \\
\hline \multicolumn{3}{|l|}{1986} \\
\hline \multicolumn{3}{|l|}{ Brown 2.5Y $4 / 4$} \\
\hline larvae & 330 & 51 \\
\hline prepupae & 171 & 26 \\
\hline Yellow 5Y 8/6-8/10 & 109 & 17 \\
\hline Red 1 OR 4/8 & 1 & $<1$ \\
\hline Negative & 38 & 6 \\
\hline Total $\%$ infected & & 94 \\
\hline
\end{tabular}

of Erynia sp. throughout the state in 1985-86 also is presented in Table 4; this organism was not known before 1974 so a survey for this pathogen was not made in 1972-73. The establishment of Erynia sp. certainly has affected alfalfa weevil populations but its role as a biocontrol agent is unknown.

\section{Hyperparasites Found in West Virginia (Table 5)}

In his 1972-73 study, Gallo found three hyperparasites attacking B. curculionis: Gelis sp.; Itoplectis conquisitor (Say); and Spilochalcis albifrons (Walsh). In 1979, from a collection of 816 B. anurus cocoons in Monongalia County, four species of hyperparasites were present: Gelis sp.; S. albifrons; Sceptrothelys intermedia (Walker); and Pteromalus (Habrocytus) sp. Total percentage hyperparasitism was 25.7 with 23.4 percent of the total being Gelis sp. [Weaver 1979, unpublished data.]

Presently, 17 species of hyperparasites are known from Bathyplectes spp., with only seven being fairly common (W. H. Day 1986, personal communication, USDA-BIRL, Newark, Delaware). The current study found all of the hyperparasites that were present in 1979 as well as Trichomalopsis, sp. and Tetrastichus coerulescens Ashmead. During all three studies in West Virginia, 


\section{Table 4}

A comparison of the distribution of established alfalfa weevil parasites and Erynia sp. in West Virginia during 1972-1973 and 1985-1986.

\begin{tabular}{|c|c|c|c|c|c|c|}
\hline \multirow[b]{2}{*}{ Parasite } & \multicolumn{6}{|c|}{ Geographical Region } \\
\hline & $\begin{array}{l}\text { North- } \\
\text { western }\end{array}$ & $\begin{array}{l}\text { North } \\
\text { Central }\end{array}$ & Central & $\begin{array}{l}\text { North- } \\
\text { eastern }\end{array}$ & Southern & $\begin{array}{l}\text { South- } \\
\text { western }\end{array}$ \\
\hline \multicolumn{7}{|l|}{$1972-1973$} \\
\hline \multicolumn{7}{|l|}{ M. a. ${ }^{1}$} \\
\hline M. c. & & $x$ & $x$ & $\mathrm{X}$ & $x$ & $x$ \\
\hline B. a. & & & $x$ & $\mathrm{X}$ & & $\mathrm{x}$ \\
\hline B. $c$. & $x$ & $x$ & $x$ & $X$ & $x$ & $\mathrm{X}$ \\
\hline $\begin{array}{l}\text { T. i. } \\
\text { Erynia sp. }\end{array}$ & & & $x$ & $x$ & $x$ & $x$ \\
\hline \multicolumn{7}{|l|}{ 1985-1986 } \\
\hline M. a. & $x$ & $x$ & $x$ & $\mathrm{X}$ & & $X$ \\
\hline M. c. & $x$ & $x$ & $x$ & $x$ & $x$ & $\mathrm{X}$ \\
\hline B. a. & $x$ & $x$ & $x$ & $x$ & $x$ & $\mathrm{X}$ \\
\hline B. $c$. & $x$ & $x$ & $x$ & $x$ & $x$ & $\mathrm{X}$ \\
\hline T. i. & $x$ & & & $x$ & & \\
\hline Erynia sp. & $x$ & $x$ & $x$ & $x$ & $x$ & $x$ \\
\hline
\end{tabular}

1M. a. = Microctonus aethiopoides

M. c. = Microctonus colesi

B. a. = Bathyplectes anurus
B. c. = Bathyplectes curculionis

T. $i .=$ Tetrastichus incertus

Table 5

Percent hyperparasitism of Bathyplectes spp.-1986. ${ }^{1}$

\begin{tabular}{llcccc}
\hline \hline County & Date & $\begin{array}{c}\text { No. of } \\
\text { fields } \\
\text { sampled }\end{array}$ & $\begin{array}{c}\text { No. } \\
\text { cocoons } \\
\text { collected }\end{array}$ & $\begin{array}{c}\text { No. hyper- } \\
\text { parasites } \\
\text { emerging }\end{array}$ & $\begin{array}{c}\text { Mean } \\
\text { \% hyper- } \\
\text { parasitized }\end{array}$ \\
\hline Ohio & $5 / 15$ & 4 & 119 & 5 & $4(0-50)^{2}$ \\
Ohio & $5 / 30$ & 4 & 227 & 118 & $52(24-96)$ \\
Monongalia & $5 / 29$ & 2 & 89 & 17 & $19(13-24)$ \\
Preston & $5 / 29$ & 2 & 11 & 5 & $45(0-63)$ \\
Greenbrier & $5 / 8$ & 3 & 35 & 2 & $6(0-8)$ \\
Berkeley & $5 / 22$ & 4 & 211 & 1 & $<1(0-2)$ \\
Jefferson & $5 / 21$ & 3 & 957 & 11 & $1(0-4)$ \\
Mason & $5 / 9$ & 4 & 176 & 3 & $2(0-5)$ \\
\hline
\end{tabular}

1 All hyperparasites combined.

2Range. 
Gelis sp. was the most common hyperparasite found as is the case in most of the East (W. H. Day 1986, personal communication, USDA-BIRL, Newark, Delaware).

Hyperparasites were found in greatest abundance in Ohio County. Although there are no data available that determine the level at which hyperparasites become detrimental, the percentages of hyperparasites found in Bathyplectes spp. from two fields in Ohio County ( 75 and 95 percent) could have serious effects on its survival.

\section{Alfalfa Weevil Populations (Table 6)}

Larval populations varied considerably among fields in several counties on particular sample dates. The extremes were observed in Ohio, Greenbrier, and Berkeley counties. For example, in 1985, the variation in number of larvae per 100 sweeps on four farms each in Ohio and Greenbrier counties were 250-1204 (April 25) and 198-3205 (April 30), respectively. In 1986, the variation on four farms each in Ohio and Berkeley counties were 133-1077 (May 30) and 62-2332 (May 22) larvae per 100 sweeps, respectively.

Population levels in counties also differed between years. Larval populations in counties on comparable sample dates in 1986 versus 1985 were higher in Ohio and Berkeley, lower in Preston and Greenbrier, and about the same in Monongalia.

On a regional basis, populations in 1986 versus 1985 were higher in the Northwestern and Northeastern regions, and lower in the North Central and Central regions. There are no yearly comparable data for the other regions.

\section{Conclusions}

In all counties sampled, $B$. anurus was the dominant parasite. This follows a trend throughout the eastern United States where $B$. anurus has replaced the once dominant B. curculionis [1, Day 1986 personal communication, USDA-BIRL, Newark, Delaware]. Another trend which seemed to be present in West Virginia was a reciprocal decline of $B$. anurus parasites as Erynia sp. infection increased, apparently due to loss of hosts and/or direct infection by Erynia sp. [5].

Gallo [2] reported that parasitism by B. curculionis seemed to be lower in mixed alfalfa stands than in pure stands. In this 1985-1986 survey, there were no consistent data to support these findings.

McKinney and Pass [6] determined that some weed species can serve as food sources (pollen and nectar from flowers) for adult B. curculionis, thereby increasing their productivity. Most of the weeds found in West Virginia were not tested by McKinney and Pass for their attractiveness as food sources. There was no apparent relationship between weedy fields and Bathyplectes spp. parasitism in West Virginia during 1985 and 1986. 
Table 6

Alfalfa weevil larval populations, 1985-86.

\begin{tabular}{|c|c|c|c|c|}
\hline County & Date & $\begin{array}{c}\text { No. of } \\
\text { fields } \\
\text { sampled }\end{array}$ & $\begin{array}{l}\text { Mean no. larvae } \\
\text { per } 100 \text { sweeps }\end{array}$ & Range \\
\hline \multicolumn{5}{|l|}{1985} \\
\hline Ohio & $4 / 25$ & 4 & 747 & $250-1204$ \\
\hline Ohio & $5 / 29$ & 2 & 205 & $75-334$ \\
\hline Monongalia & $5 / 15$ & 1 & 995 & - \\
\hline Preston & $5 / 8$ & 3 & 2023 & $1448-2383$ \\
\hline Preston & $5 / 15$ & 2 & 2007 & $1870-2144$ \\
\hline Preston & $5 / 24$ & 2 & 871 & $806-935$ \\
\hline Preston & $5 / 30$ & 2 & 122 & 89-154 \\
\hline Greenbrier & $4 / 30$ & 4 & 1222 & $198-3205$ \\
\hline Berkeley & $5 / 13$ & 2 & 286 & $101-471$ \\
\hline Jefferson & $5 / 13$ & 2 & 375 & $335-415$ \\
\hline Hardy & $5 / 13$ & 2 & 275 & $230-319$ \\
\hline \multicolumn{5}{|l|}{1986} \\
\hline Ohio & $4 / 30$ & 4 & 1638 & $892-2464$ \\
\hline Ohio & $5 / 15$ & 3 & 2227 & 2079-2334 \\
\hline Ohio & $5 / 30$ & 4 & 636 & $133-1077$ \\
\hline Monongalia & $4 / 28$ & 1 & 424 & - \\
\hline Monongalia & $5 / 6$ & 2 & 925 & 694-1155 \\
\hline Monongalia & $5 / 29$ & 2 & 331 & $183-479$ \\
\hline Preston & $5 / 6$ & 3 & 196 & $157-242$ \\
\hline Preston & $5 / 29$ & 3 & 258 & $232-291$ \\
\hline Greenbrier & $5 / 8$ & 4 & 916 & 574-1699 \\
\hline Berkeley & $5 / 1$ & 5 & 1262 & $374-2830$ \\
\hline Berkeley & $5 / 22$ & 4 & 831 & $62-2332$ \\
\hline Mason & $4 / 25$ & 4 & 919 & $833-1061$ \\
\hline Mason & $5 / 9$ & 4 & 1666 & $1165-1950$ \\
\hline
\end{tabular}

The current status of biological control agents of the alfalfa weevil in West Virginia appears to be strong. This indicates that if integrated pest management methods were used throughout the state, losses caused by weevil damage could be lowered. A cautious eye should be kept on Erynia sp. infections as they may be detrimental to populations of larval parasites in the long run. 


\section{Literature Cited}

Dowell, R. V. and D. J. Horn. 1977. Adaptive strategies of larval parasitoids of the alfalfa weevil. Can. Ent. 109:641-648.

Gallo, T. S. 1973. Parasites affecting the alfalfa weevil, Hypera postica (Gyll.), in West Virginia. M. S. Thesis, West Virginia University, 51 pp.

Hanson, C. H. (ed.). 1972. Alfalfa Science and Technology. American Society of Agronomy, Inc., Madison, Wisc., 812 pp.

Johnson, J. A., I. M. Hall, and K. Y. Arakawa. 1984. Epizootiology of Entomophthora phytonomi and Beaveria bassiana parasitizing the Egyptian alfalfa weevil in Southern California. Environ. Entomol. 13:95-99.

Los, L. M. and W. A. Allen. 1983. Incidence of Zoophthora phytonomi in Hypera postica larvae in Virginia. Environ. Entomol. 12:1318-1321.

McKinney, T. R. and B. C. Pass. 1977. Effects of various foods on the reproduction of Bathyplectes curculionis. J. Kans. Ent. Soc. 50:523-528.

Millstein, J. A., G. C. Brown, and G. L. Nordin. 1982. Microclimatic humidity influence on conidial discharge in Erynia spp., an entomogenic fungus of the alfalfa weevil. Environ. Entomol. 11:1166-1169.

Millstein, J. A., G. C. Brown, and G. L. Nordin. 1983. Microclimatic moisture and conidial production in Erynia spp.: In vivo moisture balance and conidiation phenology. Environ. Entomol. 12:1339-1343.

Millstein, J. A., G. C. Brown, and G. L. Nordin. 1983. Microclimatic moisture and conidial production in Erynia spp.: In vivo production rate and duration under constant and fluctuating moisture regimes. Environ. Entomol. 12:1344-1349.

Stuart, L. C. 1977. Field evaluations of insect growth regulators on alfalfa insect pests. M. S. Thesis, West Virginia University, 95 pp.

Van Buskirk, P. 1981. A survey and physiological study on Entomophthora phytonomi. M. S. Thesis, West Virginia University, $71 \mathrm{pp}$.

Weaver, J. E. 1976. Parasites of the alfalfa weevil in West Virginia. West Virginia University Agr. Exp. Sta. Cur. Rpt. 67, 16 pp.

Weaver, J. E. and T. S. Gallo. 1977. Studies on the parasites associated with the alfalfa weevil in West Virginia. West Virginia University Agr. Exp. Sta. Bull. 652T, 14 pp.

Weaver, J. E. 1984. Field evaluations of insecticides for control of alfalfa in West Virginia, 1981-1983. West Virginia University Agr. Exp. Sta. Cur. Rpt. $76,10 \mathrm{pp}$. 
Blank Page in Original Bulletin 
Blank Page in Original Bulletin 
